University of Warwick institutional repository: http://go.warwick.ac.uk/wrap This paper is made available online in accordance with publisher policies. Please scroll down to view the document itself. Please refer to the repository record for this item and our policy information available from the repository home page for further information.

To see the final version of this paper please visit the publisher's website. Access to the published version may require a subscription.

Author(s): Peter Burnell

Article Title: The Domestic Political Impact of Foreign Aid: Recalibrating the Research Agenda

Year of publication: 2004

Link to published version:

http://dx.doi.org/10.1080/0957881042000220868

Publisher statement: None 


\title{
The Domestic Political Impact of Foreign Aid: Recalibrating the Research
}

\section{Agenda}

\author{
Peter Burnell ${ }^{*}$
}

from The European Journal of Development Research Vol. 16 No. 2, summer 2004, pp. 396-416.

\begin{abstract}
The recent concentration of attention by some political scientists on evaluating the effectiveness of democracy assistance, drawing on the transient policy concerns of major donors, is a welcome innovation to a research agenda traditionally biased towards aid's significance for economic development. But its focus is restricted and unrepresentative. This paper argues the case for a more comprehensive assessment of the domestic political consequences - both direct and indirect - of all forms of aid, in principle for aid recipients everywhere. This recommendation offers the advantage of serving the limited purposes of analysts of democratization generally and democracy aid specifically, but more importantly reconnects their approach with the broader political analysis of aid by a wider social science community. It is important to 'think outside the box' of contemporary donor concerns, recalibrating the research agenda in ways that raise other political priorities. The article offers a framework for this purpose. Comprehending the political dynamics in aid-receiving countries should be the primary orienting principle, rather than viewing countries as objects of aid and proceeding to interpret their politics through the distorting lens of donor perspectives.
\end{abstract}

'Many donors are reluctant to acknowledge the political impacts of their aid' [Boyce, 2002b: 1032].

\section{Introduction}

This article argues the case for examining as comprehensively as is practical the domestic political effects of aid in the aid-receiving countries. By aid is meant the

\footnotetext{
* The author thanks the Journal's referees for very helfpul comments on earlier versions of this paper.
} 
usual Organisation for Economic Co-operation and Development (OECD) Development Assistance Committee (DAC) understanding of resources transferred on a concessionary basis for developmental purposes - economic, social or political. The argument proceeds by first reporting an agenda of research that has come to capture the close interest of a notable body of political scientists and aid practitioner organisations. It engages with that agenda in order to recommend moving beyond it, reconnecting with the primary interests of the study of politics as a whole, and politics in aid-receiving countries specifically. Of course ideas of politics are social and cultural constructs; what is perceived to be politically significant in one society might not resonate equally strongly elsewhere. So, studies of aid's political effects in any country must draw on that society's own understanding of politics. That said, politics is presumed to be about who gets what, when, where and how. Everywhere the distribution, use and misuse of power are central features. They cannot be examined wholly through a lens framed by the issues of democracy and democracy- promotion a moral that is not lost on the larger community of social scientists studying political aspects of development more generally and those members already researching wideranging aspects of aid politics more specifically.

Until recently a great deal of research on the effects of foreign aid focused on its economic consequences, and hence Goldsmith’s [2001: 128] observation 'More work clearly needs to be done to ascertain the extent to which aid has a destructive effect on the state'. Yet the fact is that recently there has been a surge of studies into into democracy aid, its achievements and the difficulties of evaluation (for example Blair, 2003; Burnell, 2000; Carothers, 1999; Craword, 2001; Crawford, 2003a; Crawford, 2003b), situated within a context of heightened interest in international democracy promotion more generally (Cox, Ikenberry and Inoguchi, 2000; Olsen, 2000; Santiso, 2003; Schraeder, 2002; and Youngs, 2001). In September 2003, the General Conference of the European Consortium of Political Research, held at the University of Marburg, saw an entire new cluster of research presentations on European Union aid and democracy support in particular. The idea of democracy aid or assistance is now firmly embedded in the literature. It stretches as far as aid for human rights causes and, even, aspects of 'good governance'. None of the aforementioned inquiries presume that democracy aid has been successful. On the contrary they challenge the tendency of democracy promotion agencies to talk up 
their own achievements. They question the presumption that good intentions will ensure successful outcomes - outcomes measured by yardsticks of the agencies' choosing. And some of the analysts share with a few of the aid agencies a commitment to overcome the difficulties surrounding how to measure democracy aid's performance. Nevertheless, the focus in all cases is limited, in two important respects. And for that reason it is argued here that it would be unfortunate if such research continued to proceed in a manner disconnected from other studies into aid's political effects (for example Moore and Putzel,1999 or Bräutigam, 2000), or if it captured a disproportionate share of new attention.

\section{Limitations}

First, other forms of aid than democracy aid can have consequences - positive and negative - for democracy. The consequences might reinforce democracy aid's impact on democratization, or, on the contrary nullify, or perhaps even outweigh its effects, especially where democracy aid's effects appear to be neutral or non-existent. In one of the most often vented illustrations of this problematic, the economic and social policy conditionalities that are routinely attached to economic aid threaten to empty out the significance of domestic political processes, by constraining the recipient government's scope for making choices. Responsibility for economic policy-making is externalised. The point is not simply that this hinders domestic 'ownership' of decisions but that it may prevent politicians (who may have been democratically elected) showing responsiveness to society’s felt needs and expressed wishes. That cannot be good for representative democracy - a system that presupposes accountability to the people.

As a general rule, then, the consequences of aid in its entirety should be factored into the equation even by analysts whose interest is confined to just the democracy consequences of aid. This suggests a larger frame of reference than that used by most practitioners of democracy aid when they try to measure how successful their interventions have been. But clearly a larger frame is vital if we are interested in enhancing the democratic prospect, even just western-style liberal democracy rather than some more participatory, radical ideal. Indeed, looking at all aid weakens one of the objections that is sometimes put up against subjecting democracy aid to exhaustive impact evaluations, namely that it is too insignificant for its wider impact 
to be noticeable [Crawford, 2003b]. At the very least, democracy promotion agencies should be interested in the domestic political consequences of other kinds of aid, in as much as they influence the opportunities, constraints and receptivity to democracy aid - and thereby that aid's likely effectiveness. Where, in contrast, our interest in democracy aid's effectiveness stems primarily not from an interest in democracy promotion but in democratization - in the meaning of democracy and how democratic change is propelled and by what forces - then concentration on just the democracy consequences of democracy aid is obviously insufficient.

Secondly, democracy aid and, indeed, other kinds of aid too can have larger political consequences for the recipient country than democratic consequences. These wider consequences may be much more significant than the democracy effects, as well as having implications indirectly for the condition of democracy more specifically. Furthermore as Shapiro and Hacker-Cordón [1999] remind us, democracy’s value is limited anyway: it fits uneasily with certain other values, including, possibly, important elements of economic development, and in many respects is unequal to the demands it confronts. And if the goal is to understand the domestic politics of countries that simply happen to receive aid - as this paper recommends - then just as domestic political structures influence their foreign policy behaviour, so domestic politics is influenced - explained - by the international or external relations including aid [Gourevitch, 1978].

Historically aid has taken different forms, shapes and sizes geared to a variety of aims and objectives. Some aid flows are too complex to be easily pigeon-holed into a simple category like economic aid or political aid, and in any case the problem of fungibility means that aid for one purpose can end up supporting something completely different. There is political aid that is not democracy aid, and security assistance more broadly defined, apart from the considerable resources devoted to military assistance especially during the cold war. Security-related assistance has sometimes been transferred under the guise of economic support, which challenges the DAC definition of development aid. There is support for economic development narrowly defined, aid to social development and for human development, and disaster relief or emergency aid, sometimes followed by help with rehabilitation and reconstruction. The recent exponential growth in theorising about international 
humanitarian intervention draws attention to aid for conflict-prevention and conflictresolution, for post-conflict-reconstruction and state-(re)building. Large-scale international financial transfers have also been made in response to a financial crisis or collapse of the currency. And then there are various kinds of technical assistance or advice that increasingly intrude into almost any and every facet of economic, social and political life, from macro-level processes like national planning to micro-level involvement in detailed policy execution, for example the delivery of health care. These can all have significant political effects, even without the aid-providers declaring or acknowledging explicit political objectives. The effects may or may not impinge on the democratic prospect. But they can be potentially more important in political terms than the democracy effectiveness, ineffectiveness or harmfulness to democracy of democracy aid. Development aid that purports to be about 'empowering the poor' is an obvious example especially given the politically contested understanding of that idea with donors [Moore, 2001]. All things considered, then, there are strong grounds for maintaining long-established traditions of subjecting development aid to political assessments that go well beyond the consequences for democracy.

A possible retort is that because inquiries into democracy promotion tend to be drawn to investigate the democratic conditionalities that donors regularly attach to their development co-operation, their field of vision in practice extends to most examples of economic development aid. This 'second generation' of conditionalities, like the first generation (economic conditionalities) has received considerable attention (see Stokke, 1995, for example). There are even studies contrasting the effectiveness of different approaches to democracy conditionality - the threat of sanctions versus offers of incentives or inducements [Ethier, 2003] - and comparing these with concrete programmes like support for a stronger and more autonomous judiciary, closer parliamentary scrutiny of the executive, and robust civic associations.

Yet the retort is unconvincing, for several reasons. For one, the democracy conditionalities ignore all of aid's other political conditionalities - the ones not oriented towards promoting democracy, human rights and 'good governance' - as well as conditionalities that in the first instance have different objectives: economic; social; environmental and so on. Guaranteed special access to military facilities in a country 
evokes an old-fashioned example of a form of non-democracy conditionality but one that is still not obsolete. Even economic conditionalities can have significant political effects, like allowing a government to deflect domestic political opposition to economic measures it might have taken (probably had to take) anyway. Similarly the external seal of approval that is conveyed by a package of conditional funding might help promote the authority of a new government, or help consolidate a recent change of regime. The institutional implications of economic conditionalities have indeed attracted some attention, for instance giving more power to finance ministries against spending departments. But it is in the context of explaining the failures of economic conditionalities by reason of 'defections' (in some cases voluntary and in others involuntary) that inquiries have come closest to raising questions about the domestic politics of such so-called 'slippage'. Development economists among others have made notable contributions to this kind of work [Toye, 1992; Morrissey, 1999]. But the terms of reference framing their inquiries are those spelled out in the conditionalities: naturally their main concern is not with aid's political consequences but with identifying the most favourable political environment for economic aid conditionalities and for the associated economic policies to work.

A further objection to the retort, then, is that evaluations of the performance of democracy conditionalities are confined to the consequences relating to democratization, human rights, or 'good governance', rather than wider political consequences. A tendency for the democracy assistance to accentuate sharp divisions and accelerate fissiparous tendencies in society might go unrecorded. And in any case the mood among many economists now appears to be turning against attaching conditionalities for 'good governance' to development aid, following the World Bank's report Assessing Aid (1998). That report argued for the abandonment of the conditionalities approach, in favour of targeting aid more selectively on countries already committed to 'good governance' and the like. ${ }^{1}$ It is said that 'attempting to steer governance restructuring programmes from the outside have (sic) turned out to be far more complicated and laborious engagements than self-confident and optimistic aid agencies had first assumed they would be' [Doornbos, 2001: 103]. Nevertheless it could still be argued that knowledge of aid's wider political impact would remain useful for the purpose of identifying which countries are likely to (continue to) meet the selectivity criteria and so be eligible for future aid. And here the sum total of 
conditionalities' political effects, both intended and unintended may well be far more instructive than the democracy effects of democracy conditionalities. In theory democratization, human rights and good governance could be defined so inclusively that they amount to all of politics, and thereby rebut the point. But that would be contrary to customary usage. ${ }^{2}$ Moreover to do so would risk jeopardising much of what is most valuable about the recent researches into democracy aid's effectiveness, such as its specificity and the practical definition of focus, ${ }^{3}$ while still end up conceding the general argument of this article.

Finally, by suggesting that aid's larger political impact continues to merit a greater concentration of attention than the more specialised matter of democracy aid in no way presumes that aid must always have considerable impact in practice. Where substantial aid flows to a country have no domestic political impact that can be just as revealing - both about aid and the country's political, economic and social processes as where aid reinforces the political status quo. In principle it would be no less intriguing than where democracy aid influences democratization without touching on other political variables.

\section{Learning from the Past}

Throughout much of the fifty plus years following the start of the Marshall Plan (European Recovery Programme) of 1947-51, the political effects of development aid have been a comparatively underdeveloped branch of inquiry. Notwithstanding a limited number of exceptions from other disciplines, development economists have dominated the study of development aid; they continue to account for the great bulk of new research. The economic analysis of aid was pre-eminent precisely because it shaded into theorising about economic development and observation of actual economic outcomes - activities that attracted financial support from the aid agencies. In contrast, the charter or Articles of Agreement of the pre-eminent multilateral institutions forbade explicitly political objectives. Aid's impact on politics was not their concern. United Nations agencies must respect the sovereignty of states and rights of non-intervention in internal affairs (UN Charter Article 2:7). The Bretton Woods institutions for many years took a cautious attitude towards considering the domestic political consequences of its lending decisions, although that has changed somewhat since the 1980s. Now issues to do with governance, military budgets and 
certain kinds of human rights do figure in their deliberations, where they have undeniable significance for the development performance of Bank loans. But the interpretation of the 'political' dimensions of governance that these institutions can legitimately raise with borrowers is still restricted, except when acting as a coordinating interlocutor on behalf of the donor governments. Anyway the broad thrust of much contemporary research both inside and outside these institutions revolves around aid's consequences for economic, social and to a lesser extent human development, not its political effects.

It was chiefly among American political scientists and foreign policy analysts that the political analysis of aid first developed. The concerns that recurred most often were the themes of particular interest to US foreign policy at the time: does US aid help stabilise anti-communist regimes?; does it purchase influence over the recipient governments' voting behaviour in the United Nations General Assembly?; does US military assistance make military governments reliable allies in Latin America (a US sphere of influence closely monitored during the cold war)? The likelihood that the Kennedy administration's Alliance for Progress (1962-3) would change society in Latin America (and dampen the appeal of Cuban-style communism) briefly attracted some attention, but the Alliance itself was soon abandoned. ${ }^{4}$ US aid's failure to promote human rights in the region under successive administrations but especially the Carter presidency also was studied quite carefully (for example Carleton and Stohl, 1987). This reflected Congressional and liberal academic interest in this aspect of America's manifest destiny, as much as curiosity about the internal affairs of America’s partners abroad. In the 1970s a few experts on public administration and organisation theory in public bureaucracies wrote about support for state-building in post-colonial societies. But even now it seems that the donor foreign policy rationales for aid and the lessons they should learn from experience continue to garner as much attention among political scientists as does aid's consequences in recipient countries (see for example Schraeder, Hook and Taylor, 1998).

In Europe, meanwhile, writers from the political left were more interested in showing how aid reduces third world states to dependent status, or convert their governments into 'compradors' whose behaviour could be explained largely in terms of external dependency. At its height in the 1970s this approach offered a 'one size 
fits all' interpretation. It paid little heed to subtle variations in aid's domestic political consequences and how the internal politics of partner countries mediated aid's economic and political effects in ways distinctive to the country. Now the dependency approach is less prominent (but on aid imperialism see Petras and Veltmeyer, 2002), which is ironic, because many developing countries have seen their international bargaining position eroded by the end of the cold war and collapse of the Soviet Union. Moreover much contemporary aid and much aid analysis, democracy aid included, really does tend to treat the recipients as the dependent variable - they are object and not subject. Aid is done to them, courtesy of the donors, and aid's allocation and design are geared to donor intentions. Nevertheless, in the official development discourse leftist perspectives have long since been overtaken by neoliberal thinking of the sort personified by Peter Bauer (1981), who reduced aid's political impact to an equally simplistic set of claims: aid's proclivity to politicise development policy and create 'big' government. The value of that perspective lies in publicising the fact that aid can alter the incentive structure relating to political power. But for aid's critics from both the left and the right it was still what aid meant for the prospects of development understood in terms of economic progress and social welfare, not its political consequences that was the primary concern.

Placed in historical context, then, the dramatic recent growth of interest in democracy aid's effectiveness is a welcome addition to the research agenda. But it should not be allowed to overshadow the more enduring questions about aid's political impact, which although not addressed entirely convincingly in the past continues to make a strong claim to be a more important focus of inquiry, for the following reasons.

\section{Rationale}

First, more systematic inquiry would help us decide which of the various competing big assertions from left and right has most validity and, more interestingly, under what conditions they hold most true. For example how extensive is aid's influence on major public policy outputs, and does it really shape the leading political institutions and mould endogenous political cultures in the strikingly different ways that many critics allege? Or is it so marginal to the way power is used and distributed that the issue hardly merits much further inquiry? That last speculation clearly has not 
discouraged attempts to evaluate democracy assistance: and if those attempts are at all worthwhile, then so much more so must be the investigation of aid in its entirety.

More importantly - and a cause for concern - a focus on evaluating democracy assistance and its democracy consequences necessarily structures the inquiries in particular ways, which are both restrictive and likely to distort our understanding of aid's multi-dimensional political effects. This remains true even where some thought is given to capturing the political context within which democracy aid programmes take place. Self-evidently such studies are oriented to the highly normative agenda of the policy-makers, namely their promotion of what their idea of democracy - which most closely resembles Robert Dahl's (1971) concept of polyarchy, an elitist form of democracy - and the consequences for that democracy. This agenda has been designed to suit certain values and to serve specific interests. Arguably western donors value the spread of this democracy above all for its usefulness in promoting economic liberalism and furthering their own national economic and security-related goals. Whether or not it is the optimum solution to political problems in the aid-receiving countries may not be the primary concern. And as is equally well known the human rights agenda has been challenged for privileging certain political and civil rights over their social and economic counterparts, and for advancing notions that are incompatible with certain strongly held cultural and religious beliefs. The idea of 'good governance' is manifestly a World Bank enthusiasm, which seems increasingly to circle around a narrow but shared obsession with reducing corruption. Yet as Hagopian [2000: 902] reminds us, 'we must exercise strict caution not to assume that political development implies progress toward any particular set of goals', that 'political society is lumpy, uneven, and, yes, contradictory'. He adds that it is to be expected that different parts of different political systems in different countries will 'develop’ at different rates and in different directions.

Hence, research into aid's domestic political effects should eschew identification with the contemporary prescriptive purposes of the aid policy-makers; it should get away from the 'instrumentalization of prodemocracy policies' that for instance Carothers [2003] claims is uppermost in the United States. The full range of domestic political consequences of aid tout court is not only a legitimate object of inquiry in its own right but potentially is of much greater significance to the aid 
receiving countries than just the democracy effectiveness of democracy aid. And yet it should not be without interest to the donor organisations either. For attitudes are moving in favour of a right - sometimes expressed as the duty even - of the ‘international community’ to intervene in domestic jurisdictions on behalf of citizens where their security is at risk - from their own government or from state failure. Thus although democracy promotion is not universally endorsed as sufficient justification for coercive 'humanitarian intervention' (see Pieterse, 1998), understanding how aid's distribution can affect power relations among competing interests inside aidsupported countries is 'particularly crucial in understanding the dynamics of conflict and the current globalization of violence' [Boyce, 2002a: 239]. Boyce [2002a: 239] argues that recognition of the connection between development and a country's power structures and aid's importance 'in failing states, crumbling nations and societies in disarray', is still rare in development discourse. The same point applies in some degree to the development aid discourse. ${ }^{5}$ Thus aid's impact on the presence/absence of violent conflict within states, and on state fragility or effectiveness do demand attention, and not merely because of the consequences for the possibilities of meaningful democracy (and, hence, for the object of democracy promotion and for directing aid to that end). After all, the most aid-dependent states are chiefly in subSaharan Africa, a region that contains several examples of 'failed states' and is unique in as much as the incidence of civil war did not decrease in the 1990s. Statistically, past experience of civil war increases the likelihood of similar conflicts in the future. Ergo, aid's role there could be immense.

Fashions both come and go, and so even the major donors could soon come to attach greater priority to political objectives other than either democracy or 'good governance' (if that shift is not under way already), as befits the forces driving their commitment to aid. Here, the evolution of the global security agenda post-'September $11^{\prime}$ and renewed interest in state-building/strengthening and nation-building in countries like Afghanistan comes to mind. The task of establishing the rule of law and orderly government in post-war Iraq is another example. The view that world poverty constitutes a major threat to international security and he belief that addressing socioeconomic deprivation offers the best antidote to international terrorism lends support to arguments for increased development co-operation. Part of the solution to poor development might be changing the government, but that does not mean giving 
precedence to supporting the construction of a model of democracy - not in the short term, anyway.

In fact clear signs are appearing of a return to much older ways of thinking about the relationship between democratic reform and development, downplaying the idea which became fashionable in the 1990s that democratization is functional for economic development. That idea powered support for democracy assistance among development aid communities. But generally speaking economists now reassert the more conventional view that the most efficacious way to tackle economic backwardness and poverty is to do so directly, namely through appropriate economic and social measures, supported where necessary by appropriate economic and social assistance. Certainly the United Nations Development Programme in its eye-catching Human Development Report 2002 (written largely by political consultants) gave considerable prominence to democratic governance as being central to human development, but it went on to confirm there is no strong evidential basis for attributing causal properties to democracy in respect of economic growth, let alone an automatic link to equitable social and economic development. So, not just the development aid industry's interest in attaching political conditionalities but its willingness to indulge in democracy assistance could eventually start to fade.

In any case, even at its peak democracy aid accounts for but a tiny fraction of all official development assistance - on most estimates the inclusion of 'good governance' aid does not raise the total beyond 5 per cent. What do we know about the effectiveness of democracy assistance? The answer is probably quite a lot, courtesy of the careful work of Crawford, Carothers, Blair and the like, and even more about the overall thrust of international attempts to promote democracy and so on, following recent work by Olsen, Stokke, Youngs and others. At the very least we now know better what the right questions are; we have learned which aspects need closer attention. This is an achievement. But of course the study of democracy aid mobilises bias in the political analysis of aid towards those very countries that the donors have targeted for democracy promotion.

In contrast, what have we learned about the domestic political effects of development assistance to say China, or Egypt, or India, or Pakistan, or Israel, or 
Turkey? These are important countries; and historically they are among the largest partners in official development co-operation, although not major recipients of democracy aid. In total they have accounted for a sizeable proportion of all official development assistance, and a substantial proportion of all military and security assistance too. The fact that their aid inflows are small in per capita terms and as a percentage of Gross National Product means they cannot be viewed as mere vassal states, or that dependency thinking will offer the most revealing insights.

Development scholars continue to study linkages between aid and the consequences of social change for the distribution of power and donors' attempts to refashion the instruments of governance, in some of these countries, but international relations experts seem more preoccupied with debating theoretical approaches to their discipline as a whole. Naturally their more policy-oriented inquiries among them and the field of diplomacy studies too are more interested in how aid relations contribute to international relations: the impact on relations between states or between states and international or transnational organisations, rather than the domestic politics.

\section{All Too Much?}

A possible objection to the argument that a larger and more wide-ranging investigation into aid's domestic political impact is merited states that the agenda would be far too big and unmanageable. Certainly the agenda might be large but. But as is the case with most studies of aid analysts target their inquiries selectively, such as in respect of what kind of political effects to look for and which countries to dwell on. And even at its maximum the agenda is definitely not be all-embracing, so long as it prioritises the domestic political effects in recipient countries. That excludes aid's impact on the external or international political relations of recipients - not just how it affects donor-recipient aid relations but the recipient state's external orientation and behaviour towards other states. That is not to deny those consequences could be momentous and worthy of investigation in their own right, as well as possibly having significant ‘knock-on’ effects for domestic politics.

Further additional lines of inquiry that also can be separated out rather easily refer to how the internal politics of donor countries impacts on their aid policies, for instance the lobbying by voluntary development agencies, and the consequences of aid for the donor countries' internal politics. The last is another subject that for the 
most part is under-researched, for instance the recycling of profits earned through (tied) aid-assisted projects back into political party funding and election campaigns. The distinction between internal and external relations is of course just an analytical convenience that is increasingly questioned in today's globalising world of porous national borders and growing significance to supraterritorial and supranational forces. The increasingly problematic nature of the domestic/international dichotomy cannot be emphasised too strongly. On the one hand, externally-determined aid conditionalities constrain political choices on economic, welfare and other matters inside the partner country. Indeed, in the most aid dependent and easily penetrated polities the donor community may be almost embedded in the countries' machinery of government. For example donors may determine key placements in strategic institutions like the central bank, or dictate that essential public services like health care are delivered by non-governmental organisations. Even where donors do not deliberately take sides, their presumed preferences can be constitutive of the groundrules over intra-elite struggles over power and influence the outcomes. For example in 1993 Zambia’s President Chiluba used donor disquiet about corruption to force some leading political rivals out of his government.

On the other hand, aid that crosses national borders takes shape in part from a catenation of forces within recipient countries - the aid-seekers' perceived needs and expressed wants, their lobbying, and the influence of internal politicking on the aid negotiations. This means that influence over aid decisions, how much is provided and its stated purposes do not lie solely with the donors, not least because the donors are far from being a monolithic community: they are both manipulators and manipulated. India's governments for instance have long had a reputation for formulating clear views of what they want and requiring that prospective donors respect those views. Yet the aid negotiation process and domestic perceptions of how effectively the country's representatives bargained for a favourable deal can themselves have domestic political reverberations. This means the particular form that an agreed aid 'inflow' takes might sometimes be described more revealingly as a 'withinput', even though the new resources underpinning the transfer come from abroad. Indeed this should only be expected if the fashionable ideas of 'partnership' and 'ownership' in development co-operation and development solutions were truly put into practice - 
even more so if the even more ambitious idea of local 'authorship’ was applied as well.

Clearly the extent to which the influence of politicians inside aid-receiving countries determines the nature of aid interventions from without cannot be speculated in advance. On the one side such influence appears to fall within the category of domestic 'causes' and their international effects - which appears to be the very opposite of the suggestion that more attention should be paid to the category of international 'causes' and their domestic effects. On the other side, the domestic impact of aid is itself influenced by the way aid transfers are mediated and then implemented inside the country. That can go a long way towards explaining why aid's consequences often diverge from the effects intended or anticipated by the donors. ${ }^{6}$ So, if notable actors like large landowners or politically-well connected companies are a crucial part of the story concerning aid's impact once it has 'entered the country', then to exclude from analysis their possible influence at the stage of aid negotiation looks to be indefensible. Negotiations over international support for infrastructure developments that will serve natural resource extraction concessions operated by members of the ruling civilian or military elite are a classic example, in Indonesia for example. The influence that such actors will attempt to exert ex ante and then ex post may to some extent be substitutable: successful influence at one stage could obviate active involvement in the other; (predicted) failure at one stage spurs stronger engagement in the other. ${ }^{7}$ If, however, the distinction between domestic and international really does make the research more manageable - a pragmatic argument - then counter-claims that such a distinction fails to recognise the global interdependence of today's world only reinforce the case for investigating the domestic political effects of all kinds of aid.

\section{Framing Research}

Analytical frameworks are heuristic devices, and an overly prescriptive approach can be counter-productive when studying such complex and contested subject matter as politics. The relative value of the alternatives will become fully apparent only after they have been tested in action. One possible approach - a simple classification for structuring inquiries into aid's impact on domestic politics - would start by distinguishing between policies, institutions, and the political culture. The effects on 
public policy might be the most immediately observable and easily measurable, but ultimately an impact on culture or institutions could be potentially more profound. The three variables are of course interdependent: policies might be impacted directly by aid and/or indirectly through aid's effects on culture and institutions. In respect of policy it is important to distinguish between policy outputs and their outcomes: for example it is well known that structural adjustment lending has levered economic policy changes in many countries but produced some adverse economic as well as social and political effects.

Among institutions, both formal and informal, the policy-making process has particular significance. The last fifteen years or so have seen deliberate attempts by donors to restructure institutions of governance, strengthening central financial management (central bank autonomy for example) and making proposals for decentralisation. But informal institutions like neo-patrimonialism and clientelism can prove highly resilient, and undermine the aforementioned efforts. The way governments influence the distribution of wealth and the way the possession of money can influence such phenomena as party politics and electoral behaviour might change very little. One hypothesis is that aid inflows actually feed neo-patrimonial and clientelistic politics; another is that aid decline, which puts a ruling group's control over scarce resources at a premium, actually tightens the grip of such informal politics. More detailed research on this would be helpful. And finally there is the question of aid's potential impact on the political culture - norms, beliefs, sentiments, and expectations - ranging well beyond recent donor attempts at sponsoring 'voter education', to include such values as the sense of national identity, or, conversely, distinct group identities within society.

A different and somewhat more elaborate framework for examining aid's political impact would differentiate between such objects as the state, political society (including political parties), civil society, society more generally (social structure, norms and national identity) and economy. The analysis would then proceed beyond these categories per se down to the level of their individual components or members (e.g. individual government departments), to relations among members (e.g. interdepartmental relations) or within categories (e.g. central-local relations) and across categories (e.g. governmental and non-governmental sectors). The precise line of 
inquiry would vary from one unit or level of analysis to another. For instance in the case of the state, questions about aid's impact on its size, structure, autonomy, capabilities, and sense of purpose - the very idea of the state - would differ from questions about the stability, legitimacy and degree of democratic accountability that might be asked about the political regime. Aid's consequences for the authority and policy performance of a government will not be the same as issues relating to civil society's capacity to articulate political demands, relations between civil society and political parties (or with society more generally), and degree of social cohesion or national integration.

In all of this there are significant gaps in knowledge. But the principle that productive research can be done in this general area is already well supported in the work of a minority of social scientists who have set about exposing specific strands, issues or themes to closer scrutiny. They provide guidance to possible ways forward. Such studies include those of aid and governance (which is not necessarily the same as donor conceptions of 'good governance'), of how aid might contribute more to developing the political capabilities of the poor, and the political significance of aid's interaction with non-governmental organisations and civil society. Leading examples of the last include Hulme and Edwards [1997], Van Rooy [1998] and Biekart [1999]and Blair's [2004] most recent work on a civil society advocacy scale and participation. On the first, Bräutigam’s work shows that aid can overburden public institutions and weaken state capacity. Together with Botchwey she draws attention to how aid and its restraints can inhibit governments from developing their own 'extractive capacity', leading to budget fragmentation and revenue instability, as well as undermining domestic responsiveness and democratic decision-making [Bräutigam and Botchwey, 1999; see also Bräutigam, 2000]. And although researchers in the West have customarily enjoyed most access to publishing opportunities, the developing world continues to give voice to its own critical tradition on aid including in its political aspects, following the dependency analyses (1970s) and 1980s critiques of the 'Washington consensus' [see Hutchful, 1987]. Thus more recent studies include sharply informed accounts of how donor interventions reduce government to almost a bystander in the development process in its own country - Zambia [Saasa and Carlsson, 1996; Saasa with Carlsson, 2002]. 
The donors' professions of support for 'capacity-building' where states have been shown to be weak or ineffective - unable even to provide an adequate regulatory environment or the security of property rights that a functioning market economy requires - merits close investigation. On this, Morss's [1984] early findings that the demands imposed by a proliferation of donors and their interventions bring about ‘institutional destruction’ may be seen as a forerunner of Brautigam’s more contemporary work. That in turn has similarities with the thesis put forward by Moore and others (see IDS, 2002] that aid dependence prevents states developing accountability to their citizens. The logic of Moore and Putzel's [1999] own recommendation that donors should engage more in political analysis, if they are to improve aid's record in reducing poverty, actually bears out the reasoning in this article. They go on to offer an analytical framework identifying how aid might serve the cause of the poor in the context of differences in political institutionalisation and electoral competition. They restate the importance of an effective state and appropriate political parties, thereby departing from the fashionable view among some donors that poverty amelioration should be the responsibility of non-governmental organisations (NGOs). Indeed, a more participatory approach to formulating poverty reduction strategies, by involving in-country NGOs, is currently being promoted by the World Bank. The potential benefits of this for governments' institutional capacity are being actively considered [see Overseas Development Institute, 2001]. Yet Moore and Putzels's [1999:11] advice to both government agencies and NGOs is 'focus more on creating incentives to collective action, above all by removing the obstacles they themselves create.' (This advice carries specific policy implications for international aid. These are pioneering analyses, but although sometimes the product of donor commissions, in this instance the World Bank's 2000/01 World Development Report: Attacking poverty ultimately did not reflect the ideas for empowering the poor that Moore and Putzel included in their background paper [ODI, 2000: para. 3]. The moral could be that if the voice of scholars is to translate more obviously into influence, then even greater attention to dissecting aid's domestic political impact - actual and potential - would hardly come amiss.

It is clear from all of this that establishing aid's effects and identifying how aid affects are not two separate exercises but are part and parcel of the same inquiry: to certify the first, we must try to make sense of the second. Moreover investigating 
aid's effects should also take in the political consequences of aid cut-offs and withdrawals, even where those anti-aid actions are not obviously politically-motivated but are responding to resource constraints on donors or doubts about aid's developmental effectiveness. The political effects of aid increases and declines, offers and denials, may not be symmetrical. Also, although it is self-evident that establishing aid's unintended consequences can be as valuable as measuring the intended effects, should analysis be restricted only to the direct or 'first round' effects? The answer is clearly no if it is outcomes that are viewed as being most significant; the political effects that follow indirectly from aid, including aid for economic or social objectives like poverty reduction such as through strengthening the non-governmental sector, could be weighty and enduring. So, just as a transfer of resources and any conditionalities that are attached might impact differently on different political constituencies, so the uses to which the additional resources are put can have notable political consequences - and these will not be summed up by measuring the initial allocations alone. This means there are a number of routes by which aid can exert political effects, of which the direct political impact of political aid is only the most obvious. The potential order of complexity is such that pragmatic considerations are bound to influence how many can be incorporated in any single study. But for analysts whose interests remain tightly focused on democracy and democratization, the possible permutations are easily summarised. For each combination of, on the one hand aid's impact on democracy/democratization, and on the other hand its impact on other aspects of the polity, the overall impact could be: positive in both cases; negative in both cases; positive in one (either) case and negative in the other case; positive in one (either) case and neutral or nil in the other; negative in one (either) case and neutral or nil in the other; neutral or nil in both cases. The terms positive and negative here are of course value-laden, and disagreements over judgments such as these, and over what counts as strong or sufficient evidence are unavoidable. And while effects that reinforce or consolidate the political status quo could be as noteworthy as any that produce change it is also worth repeating that in some cases there may be no strong effects at all - the relevance of individual lines of inquiry will vary from country to country. 


\section{Four Big Hypotheses}

Researchers must define their own points of departure, which may at times be expressly connected with democratization, such as for instance the proposition that democracy aid is a more effective instrument than economic development assistance for achieving a sustainable transition to democracy. But so long as our understanding of aid's political impact in the aggregate is more impressionistic and subject to large competing claims than a clearly defined consensus firmly grounded in systematic and exhaustive research, readers are entitled to see a specific research proposal. An examination of the long established literature together with the most recent contributions hints at least four big hypotheses that are worthy of investigation. They embody the combination of state, power and nation that constitute the defining political problematics of many - if by no means all - developing countries today. Their superficial simplicity could belie the actualité on the ground. Observers of the democracy effects of democracy aid are of course welcome to join the search for answers that would enable us to either confirm or refute the propositions below beyond all reasonable doubt:

- Aid has less overall political impact in large countries with relatively strong states than in small countries with weak states. ${ }^{8}$

- Aid impacts on the state most strongly in the economically weaker and financially most dependent countries.

- Aid's capacity to contribute to redistributing power by way of reducing poverty is modest, except possibly in the very long term.

- Aid can be an effective tool for nation-building but only under certain identifiable conditions whose presence should not be assumed.

Here is not the place to rehearse the respective merits of single-country longitudinal studies informed by speculation on the hypothetical counterfactual versus an appropriate choice of countries for comparative analysis. Suffice to say that testing and re-testing propositions like the ones above involve qualitative interpretations of evidence and judgmental reasoning at least as much as quantitative surveys of data. Insights by sources inside the country(ies) selected for study remain crucial in order to balance and correct the arguments of social scientists and country specialists who 
observe aid's impact from the outside. Here, Saasa’s work with Carlsson [1996; 2002] offers a good example.

\section{Conclusion}

The study of aid has moved on from a period when economists cared most (and they cared about the economics of aid) and political scientists were preoccupied with cold war concerns relating to the donors' foreign policy, to today's fascination with the effectiveness of democracy aid. That fascination takes its lead from the donors still, notwithstanding that the donors' own agendas have evolved and are somewhat different from before. Traditionally economists tended to focus on one indicator of performance above all others - aid's impact on economic growth. More recently, some economists and their allies have once again chosen to privilege a single but different notable performance indicator, namely aid's impact on poverty. Although the political study of aid still marches across quite a broad front, reflecting the diverse orientations and expertise of the many analysts who study it, the rather specialised subject of democracy aid's impact on democracy has recently garnered considerable emphasis, borne along initially by the development industry's willingness to consider that political reform may be a (pre)requisite for socio-economic development and for development aid effectiveness.

The quest for ever more scientifically accurate measurements of democracy aid's performance, while valuable in itself and especially where the lessons can be applied to evaluating other kinds of aid, risks lending a spurious significance to findings that ignore the political consequences of other aid interventions. Indeed, the separation of an analytically distinct category of democracy aid is probably not helpful to the study of aid's democratic implications, let alone its wider political consequences. A more joined-up approach to studying aid is more likely to enhance our knowledge and understanding than by cultivating a separate democracy aid niche. There are plenty of avenues for a combination of the legacy of literature from former decades and contemporary political developments to structure an orderly, short list of big hypotheses worthy of further investigation. In following them up the case for continuing to learn from other disciplines than political science that are currently exploring political aspects of aid is no less strong than in respect of studying democratization itself [see Burnell, 2003]. Contemporary research such as that into 
governance, non-governmental organisations and the political mobilisation of the poor could be said to be already leading the way.

Even a comprehensive audit of aid's democracy achievements cannot be confined to just examples of democracy aid. Democracy aid is but a small fraction of all aid, and is only part of the aid that does have expressly political objectives. We could all take more interest in the domestic politics of aid in those major aid recipients where democracy aid is barely on the agenda - indeed, in places where democratization is not the principal fascination of the donors, or of the recipients or the political analysts who study these countries. That includes states that may be established democracies already, India for example. It also includes states where donors believe democratization is too risky (Pakistan, perhaps) or democracypromotion is too difficult and likely to be unproductive (for example China). It also includes countries where the main political issues are not captured by reference to democratization - where democratization is a distorting lens when used as a framework to study the country's politics (Egypt, for example). The case will become irresistible if new theorising about development and the goals formally adopted for international development assistance change in step with the emergence of new perceived 'threats' to international security - for instance an increasing salience of state failure, or impending environmental catastrophe. Most important of all, assessing aid's political impact rather than evaluating democracy aid's effectiveness claims for political science an undertaking to explain the politics of countries not as the objects of western interference but as legitimate subjects of inquiry in their own right.

\section{References}

Addison, T. (ed.), 2003, From Conflict to Reconstruction in Africa, Oxford: Oxford University Press.

Bauer, P., 1981, Equality, the Third World and Economic Delusion, London: Weidenfeld and Nicolson.

Biekart, K. (ed.), 1999, The Politics of Civil Society Building, Utrecht: International Books; Amsterdam: Transnational Institute. 
Blair, H., 2003, ‘Jump-starting Democracy: Adult Civic Education and Democratic Participation in Three Countries', Democratization, Vol. 10, No.1, pp. 53-76.

Blair, H., 2004, 'Assessing Civil Society Impact for Democracy Programmes: Using an Advocacy Scale in Indonesia and the Philippines', Democratization, Vol. 11, No. 1, pp. 78-104.

Boyce, J. ,2002a, 'Unpacking Aid', Development and Change, Vol. 33, No. 2, pp.239-46.

Boyce, J., 2002b, ‘Aid Conditionality as a Tool for Peace-building: Opportunities and Constraints', Development and Change, Vol. 33, No. 2 , pp. 1025-48.

Bräutigam, D. , 2000, Aid dependence and governance. Swedish Ministry of Foreign Affairs , Expert Group on Development Issues Report No. 1, Stockholm: Almqvist and Wicksell International.

Bräutigam, D. and Botchwey, K., 1999, The Institutional Impact of Aid Dependence on Recipients in Africa, Bergen: Chr. Michelsen Institute Working Paper 1999:1.

Burnell, P. (ed.), 2000, Democracy Assistance, London: Frank Cass, 2000.

Burnell, P. (ed.), 2003, Democratization through the looking-glass, Manchester: Manchester University Press.

Carleton, D. and M. Stohl ,1987, 'The Role of Human Rights in U.S. Foreign Assistance Policy: A Critique and Reappraisal', American Journal of Political Science, Vol. 31, No. 4, pp. 1002-1018.

Carothers, T., 1997, Democracy Assistance: the Question of Strategy, Vol. 4, No.3, pp.109-32.

Carothers, T., 1999, Aiding Democracy Abroad. The Learning Curve, Washington, DC: Carnegie Endowment for International Peace.

Carothers, T., 2003, 'Promoting Democracy and Fighting Terror’, Foreign Affairs, January/February.

Cohen, J., M. Grindle and S. Walker, 1985, 'Foreign Aid and Conditions Precedent: Political and Bureaucratic Dimensions', World Development, Vol. 13, No. 12, pp. 1211-30.

Collier, P., L. Elliott, H. Hegre, A. Hoeffler, M. Reynal-Querol and N. Sambanis, 2003, Breaking the Conflict Trap, Washington, DC: World Bank. 
Cox, M., J. Ikenberry and T. Inoguchi (eds.), 2000, American Democracy Promotion: Impulses, Strategies and Impacts, Oxford: Oxford University Press.

Crawford, G., 2000, 'Promoting Democratic Governance in the South', European Journal of Development Research, Vol. 12, No.1, pp. 49-50.

Crawford, G., 2001, Foreign Aid and Political Reform, Basingstoke: Palgrave.

Crawford, G., 2003a,'Promoting Democracy from Without: Learning from Within (Part I)', Democratization, Vol. 10, No.1, pp77-98.

Crawford, G., 2003b, ‘Promoting Democracy From Without - Learning From Within (Part II)', Democratization, Vol. 10, No. 2, pp. 1-20.

Dahl, R., 1971, Polyarchy: participation and opposition, New Haven, CT and London: Yale University Press.

Doornbos, M., 2001, “'Good Governance”: The Rise and Decline of a Policy Metaphor?’, Journal of Development Studies, Vol. 37, No. 6, pp. 93-108.

Ethier, D., 2003, ‘'Is Democracy Promotion Effective? Comparing Conditionality and Incentives’, Democratization, Vol. 10, No. 1, pp. 99-120.

Goldsmith, A. A., 2001: 'Foreign Aid and Statehood in Africa', International Organisation, Vol. 55, No. 1, pp. 123-28.

Gourevitch, P., 1978, 'The Second Image Reversed: the International Sources of Domestic Politics’, International Organisation, Vol. 32, No. 4, pp. 881-911.

Hagopian, F., 2000, ‘ Political Development, Revisited’, Comparative Political Studies’, Comparative Political Studies, Vol. 33, No. 6/7, pp. 880-911.

Hout, W., 2002, 'Good Governance and Aid: Selectivity Criteria in Development Assistance', Development and Change, Vol. 33, No. 3, pp.511-27.

Hulme, D. and Edwards, M., 1997, NGOs, States and Donors. Too Close for Comfort?, Basingstoke: Macmillan.

Hutchful, E., 1987, The IMF and Ghana: the Confidential Record, London: Zed Press.

IDS Bulletin, Vol. 33, No. 3, 2002:‘The New Politics of Taxation and Accountability’. Moore, M., 2001, 'Empowerment at Last?', Journal of International Development, Vol. 13, No. 3, pp. 321-9.

Moore, J. and Putzel, J., 1999, Politics and Poverty: A Background Paper for the World Development Report 2000/1, at http:/www.worldbank.org/poverty/wdrpoverty/dfid 
Morrissey, O., 1999, ‘Political Economy Dimensions of Economic Policy Reform’, in M. McGillivray and O. Morrissey (eds.), Evaluation Economic Liberalization, Basingstoke: Macmillan, pp. 83-102.

Morss, E., 1984, 'Institutional Destruction Resulting from Donor and Project Proliferation in sub-Saharan African Countries’, World Development, Vol. 12, No. 4, pp. 465-70.

Mosley, P., 1985, 'The Political Economy of Foreign Aid: A Model for the Market for a Public Good', Economic Development and Cultural Change, Vol.33, No.2, pp.373-94.

Olsen, G. R., 2000, 'Promotion of Democracy as a Foreign Policy Instrument of “Europe”: Limits to International Idealism', Democratization, Vol. 7, No. 2, pp. 142-67.

Overseas Development Institute, 2000, 'Putting politics into poverty reduction? The WDR on empowerment. Summary of meeting held at ODI $8^{\text {th }}$ November 2000'.

Overseas Development Institute, 2001, PRSP Institutionalisation Study: Final Report, London: ODI.

Pakenham, R.,1973, Liberal America and the Third World. Political Development Ideas in Foreign Aid and Social Science, Princeton, NJ: Princeton University Press.

Petras, J. and H. Veltmeyer, 2002, ‘Age of Reverse Aid: Neo-liberalism as Catalyst of Regression', Development and Change, Vol. 33, No. 2, pp. 281-93.

Pieterse, J. Nederveen (ed.), 1998, World Orders in the Making. Humanitarian Intervention and Beyond, Basingstoke: Macmillan.

Pronk, J., 2000, 'Aid as a Catalyst', Development and Change, Volume 32, No. 4, pp. 611-29.

Putnam, R., 1988, ‘Diplomacy and Domestic Politics: the Logic of Two-Level Games’, International Organisation, Vol. 42, No. 3, pp.427-60.

Saasa, O. and J. Carlsson, 1996, The Aid Relationship in Zambia. A Conflict Scenario, Uppsala: Nordiska Afrikainstituet.

Saasa, O. with J. Carlsson, 2002, Aid and Poverty Reduction in Zambia. Mission Unaccomplished, Uppsala: Nordiska Afrikainstitutet. 
Santiso, C., 2003, 'Responding to Democratic Decay and Crises of Governance: the European Union and the Convention of Cotonou', Democratization, Vol. 10, No.3, pp. 148-72.

Schraeder, P, S. Hook and B. Taylor, 1998, 'Clarifying the Foreign Aid Puzzle. A Comparison of American, Japanese, French and Swedish Aid Flows', World Politics, Vol. 50, No. 2, pp. 294-323.

Schraeder, P.,2002, Exporting Democracy: Rhetoric vs Reality, Boulder, CO and London : Lynne Rienner.

Shapiro, I. and Hacker-Cordón, C. (eds.), 1999, Democracy’s Value, Cambridge: Cambridge University Press.

Stokke, O. (ed.), 1995, Aid and Political Conditionality, London: Frank Cass.

Toye, J., 1992, 'Interest Group Politics and the Implementation of Adjustment Policies in sub-saharan Africa', in P. Mosley (ed.), Development Finance and Policy Reform: Essays in the Theory and Practice of Conditionality in Less Developed Countries, Basingstoke: Macmillan.

Van Rooy, A. (ed.), 1998, Civil Society and the Aid Industry, London: Earthscan.

World Bank,1998, Assessing Aid. What Works, What Doesn't, and Why, New York: Oxford University Press for World Bank.

Youngs, R., 2001, The European Union and the Promotion of Democracy, Oxford: Oxford University Press.

1. On the World Bank's (1998) case that targeting would improve aid's effectiveness relative to conditioned aid see Doornbos (2001) and Hout (2002).

2. 'Good governance' for example is 'evidently not to be equated with "politics”, let alone “political leadership”’. Doornbos (2001: 95).

3. 'It is surely preferable to look at specific forms of aid, in specific circumstances, to specific countries, in order to reach specific objectives. These are the only aid evaluations that make sense'. Pronk (2000: 620).

4. Relevant themes are discussed by Pakenham (1973). Pakenham concluded that political development theories exercised little direct impact on official aid, unlike the influence of economic and cold war doctrines. He argued aid should aim at securing political development other than democracy, such as political 
capacity, national integration, and participation, for the purpose of promoting goals like social justice, economic development and personal freedom.

5. Aid probably has not yet exhausted its potential to contribute to violent internal conflict, but ways in which aid can help pull societies back from such conflict and/or prevent its recurrence are beginning to be addressed. See for example Addison (2003) and Collier et al. (2003), chapter 6. On aid's less damaging but still dysfunctional effects on governance capabilities especially in Africa see Bräutigam and Botchwey (1999).

6. On this a pioneering article was Cohen, Grindle and Walker (1985); see also Morrissey (1999).

7. Putnam's (1988) concept of a two-level game is helpful here. He argued that neither the game at the national level (domestic pressures pursing particular interests) nor the international level (governments pursuing scope to satisfy domestic pressures) can be ignored. His particular, however, was the domestic impact on negotiating positions in international trade, not the domestic impact of the trade negotiation outcomes.

8. The proposition might seem intuitively obvious, but it does not sit easily with the familiar argument that the weaker the state the stronger will be its relative bargaining position internationally. A state enjoying little autonomy of domestic pressures is unable to make concessions in international negotiations that it feels unable to sell and deliver at home; conversely the stronger the state, the weaker its relative bargaining position internationally. Putnam (1988: 449). 